\title{
SOSIAALITYÖ JA TYÖTTÖMYYS ${ }^{1}$
}

\author{
Mikko Mäntysaari: Professori (emeritus), Ybteiskuntatieteiden ja filosofian laitos, Iyväskylän yliopisto \\ mikko.j.mantysaari@jyu.fi \\ Janus vol. 27 (2) 2019, $\mathrm{xxx}-\mathrm{xxx}$
}

Millainen TIEDE SOSIAALITYÖ ON?

Professori Bo Vinnerljung Tukholman yliopistosta, erinomainen sosiaalityön tutkija, vieraili Jyväskylässä vuonna 2002. Vierailun aikana keskustelimme ruotsalaisesta sosiaalityön tutkimuksesta. Esille nousi eräs yhteinen kollegamme, joka Bossen mukaan oli sanonut hänelle välttävänsä sosiaalityön vaikuttavuustutkimusta koska hän "tekee perustutkimusta”. Vinnerljungin mielestä tämä oli lähinnä naurettavaa, sillä sosiaalityön kaltaisella tutkimusalalla ei perustutkimuksesta puhumisessa ole mieltä.

Silti sellaista yritetään. Yorkin yliopiston sosiaalityön professori Ian Shaw pohtii tuoreessa kirjassaan "Social Work Science" (Shaw 2016) sosiaalityön olemusta tieteenä. Shaw on tehnyt pitkän uran sosiaalityön tutkimuksen edistämiseksi, ja hän hakee kirjassaan monesta eri näkökulmasta vastausta kysymykseen, millainen tiede sosiaalityö oikeastaan on. Shaw koettaa sovittaa yhteen sosiaalista konstruktionismia ja näyttöön perustuvia käytäntöjä. Tarkastelua täydentää laaja ja monipuolinen historiallinen katsaus sosiaalityön akatemisoitumisesta eri maissa. Oppinut teksti sisältää monia oivalluksia, mutta kokonaisuus jää kaikessa moniulotteisuudessaan sekavaksi. Stephen Webb väittää hyvin kriittisessä arviossaan, että Shaw epäonnistuu sosiaalityön tiedeluonteen pohtimisessaan täysin. Latourin tieteensosiologiasta innostuneen Webbin mielestä sen sanominen, että sosiaalityö on tiede, tai että se on tieteellistä, on kuin sanoisi, että sähköisen leivänpaahtimen keksimisen vuoksi meidän ei tarvitse välittää Foucaultista. Webbin mukaan - latourilaisesti - tiede on sitä mitä tutkijat tekevät. (Webb 2018)

Eräänlaisen kuvan sosiaalityöstä tieteenä tai tutkimusalana voisi siten saada tarkastelemalla minun tekemisiäni. Olen Jyväskylän yliopistoon tuloni jälkeen tutkinut monenlaista, tehnyt evaluaatiotutkimuksia, ennakoinut Sotenna-projektissa sosiaalialan työvoimatarpeita, tutkinut VISH-hankkeessa erikoissairaanhoidon toimintatapoja lähisuhdeväkivallan tunnistamisessa ja AMKU-hankkeessa Kelan ammatillisen kuntoutuksen palveluita. Näistä kaikista teemoista voisin puhua.

Valitsin tämän jäähyväisluentoni aiheeksi työttömyyden ja työttömille suunnattuja palvelujen vaikuttavuuden. Minulla on kaksi viestiä: toinen maan hallitukselle, toinen sosiaalityön tutkijayhteisölle. 


\section{TYÖтTÖMYYDESTÄ}

Työttömyys on edelleen keskeinen yhteiskunnallinen ongelma. Vaikka työttömyys on viime aikoina ollut voimakkaassa laskussa, on erityisesti pitkäaikaistyöttömyys edelleen merkittävä ongelma. Pitkäaikaistyöttömyyskin on vähentynyt: elokuussa 2016 pitkäaikaistyöttömiä oli noin 130 000, kahta vuotta myöhemmin heitä oli noin 73 000 (TEM 2016, 2018).

Työttömyys on merkittävä riski ihmisen hyvinvoinnille ja terveydelle. Tästä on olemassa erittäin selkeää näyttöä sekä kansainvälisestä että myös kotimaisesta tutkimuksesta. Erityisen haitallista työttömyys on pitkittyessään. Työttömien elinajanodote on alhaisempi ja itsemurhariski korkeampi kuin kansalaisilla keskimäärin. Masentuneisuus on yleisempää kuin työssäkäyvillä. Päihdeongelmat ovat työttömillä yleisempiä kuin työssäkäyvillä. Univaikeudet, tupakointi, vääränlaiset ruokailutottumukset ja vähäinen liikunta lisäävät terveyshaittoja. Uudelleentyöllistyminen johtaa usein erilaisten terveyshaittojen vähenemiseen. Jostakin syystä erityisesti miehet näyttävät kärsivän pitkäaikaistyöttömyyteen liittyvistä riskeistä.

\section{Sipilän hallituksen ratkaisut}

Juha Sipilän hallitus on linjannut sosiaali- ja terveydenhuollon palvelujen uudistamisen rinnalle monia muitakin merkittäviä tavoitteita. Yksi julkisuudessa aika vähälle huomiolle jäänyt mutta merkittävä uudistusesitys on hallituksen tavoittelema työvoimapalveluiden uudistaminen.
Nk. kasvupalvelu-uudistus (HE 93/2018 vp) liittyy kiinteästi maakuntauudistukseen. Tarkoitus on lakkauttaa TE-keskukset ja siirtää työvoimapalveluiden järjestäminen maakuntien tehtäväksi. Myös yksityisiä työvoimapalveluita vahvistetaan. Sen sijaan kuntien työllistämistoimille ei löydy esityksestä tukea. Lait on tarkoitus saattaa voimaan vuoden 2020 alusta. $^{2}$

TE-keskusten lakkauttaminen merkitsisi myös vuodesta 2012 käynnissä olleen työllistymistä edistävän monialaisen yhteispalvelun eli TYP-toiminnan lopettamista nykymuodossaan. Nykyisessä mallissa TE-toimistojen alueilla toimii yhteensä 33 työllistymistä edistävää monialaista yhteispalvelua järjestävää verkostoa. Näitä nk.TYP-palveluita tarjotaan työttömille, joiden työttömyys on kestänyt yhtäjaksoisesti vähintään 12 kk (yli 25 vuotiailla). Monialainen yhteispalvelu alkaa enintään $3 \mathrm{kk}$ pituisella kartoitusjaksolla, jonka aikana työttömän palvelutarve arvioidaan, työttömän ammattitaitoa ja osaamista selvitetään sekä tutkitaan työllistymiseen vaikuttavia tekijöitä sekä sosiaaliselta että terveydentilan kannalta. Hallituksen esityksessä laki työllistymistä edistävästä monialaisesta palvelusta kumottaisiin ja uuteen lakiin otettaisiin yksi pykälä (13 §).Vastuu TYP-palveluiden toteuttamisesta muodossa tai toisessa siirrettäisiin maakunnille. TYP-toimintaa edistettäisiin maakuntien ja palvelutuottajien toimesta.

Sen sijaan kuntien rooli TYP-palveluiden järjestämisessä jää esityksessä vähälle huomiolle. Tämä on tärkeää, koska tällä hetkellä TYP-palveluiden toteuttamisessa kunnilla on keskeinen rooli. Hallituksen esityksen taustamuis- 
tiossa arvioidaan, että TYP-toimintaan osallistuvista kuntien henkilöstöstä $2 / 3$ ei työskentele sosiaali- ja terveyspalveluissa. Siten he eivät ole siirtymässä maakuntien palvelukseen, mikäli soteuudistus toteutuu. Hallituksen esitys (Valtioneuvosto, 2018) jättää TYP-palvelujen tarkemmat toteuttamisen muodot määrittelemättä, mikä ei sinänsä ole ihme, koska koko makunta- ja soteuudistus on edelleen enemmän tai vähemmän kesken.

Entä sitten - voisi joku kysyä. Vastaus: meillä on tutkittua tietoa siitä, että TYP-toimintaa ei tulisi lopettaa, ei ainakaan ilman, että tilalle luotaisiin varmasti toimivampi ja kustannustehokkaampi vaihtoehto.

\section{PromeQ}

Suomen Akatemian Strategisen tutkimuksen neuvoston rahoittama Osallistava terveyden ja hyvinvoinnin edistäminen (Promeq) - tutkimuskonsortiota (pätösnro 303654) johtaa professori Marja Vaarama Itä-Suomen yliopistosta. Mukana on viisi yliopistoa ja kaksi tutkimuslaitosta ja tutkimus toteutetaan toukokuun 2016 ja elokuun 2019 välisenä aikana.

Promeq:ssa tutkitaan haavoittuvassa asemassa olevien ihmisryhmien hyvinvoinnin ja terveyden edistämistä. Tutkimme NEET-nuoria, ikääntyneitä, maahanmuuttajia ja pitkäaikaistyöttömiä. Promeqin pitkäaikaistyöttömiä koskevassa työpaketissa on sovellettu kvasikokeellista asetelmaa TYP-toimintaan sisältyvän monialaisen palveluneuvonnan vaikuttavuuden arvioimiseksi.Tutkimusryhmään ovat kuuluneet lisäkseni Sami Ylistö, Kaisa Rikalainen ja Oxana Krutova sekä tutkimusapulaiset Mikko Kasanen ja Satu Sironen.

Työvoimapalveluita ja työvoimapoliittisia toimenpiteitä on yleensä arvioitu taloudellisin kriteerein (uudelleentyöllistyminen ja köyhyyden vähentäminen), mutta niiden vaikutuksia työttömien terveyteen ja hyvinvointiin on tutkittu vähän tai niihin viitataan toteamalla, että interventio on tuottanut sivuvaikutuksena myös hyvinvointivaikutuksia (Hänninen \& Karjalainen 2012; Sage 2013; 2015). WP4:n tutkimustehtävänä on selvittää, millaisia vaikutuksia TYP-toimintaan sisältyvällä palveluneuvonnalla on tätä palvelua käyttävien pitkäaikaistyöttömien hyvinvointiin ja terveyteen.

\section{Tutkimusasetelma}

Keräsimme tutkimustamme varten ensin kohtalaisen laajan kvalitatiivisen aineiston, mutta emme pitäneet mahdollisena arvioida tarkastellun palvelun vaikuttavuutta vain tämän laadullisen aineiston avulla. Toteutimme koeasetelmaan pohjautuvan tutkimuksen, jossa koeryhmään valitut ihmiset tulivat uusista TYP-palveluiden käyttäjistä. Heille valittiin verrokit URA-tietokannasta poimimalla satunnaisesti 1571 pitkäaikaistyötöntä tutkimusalueilta. Alkumittaukseen osallistui 492 vastaajaa, joista 92 kuului koeryhmään ja 400 kontrolliryhmään. Loppumittaukseen osallistui yhteensä 75 paria.

Päädyimme käyttämään TYP-toiminnan vaikutusten arvioinnissa osallistumistodennäköisyyksien etäisyyden laskemiseen perustuvaa propensity score matching -menetelmää (PSM). PSM- 
menetelmän eli vertaistamisen avulla voidaan tehdä vertailu koe- ja kontrolliryhmän välillä mahdolliseksi, vaikka molemmat ryhmät eivät olekaan satunnaistettu. (Parsons 2001; Rosenbaum \& Rubin 2006, 42). Tutkimuksessa sovellettu PSM menetelmä vähensi koeasetelman avulla saatujen tulosten tulkintaan sisältyviä riskejä.

TYP-toiminnan vaikutukset pitkäaikaistyöttömien hyvinvointiin

Käytimme hyvinvoinnin mittaamisessa WHOQOL-BREF -elämänlaatumittaria, toimintamahdollisuuksia mittaavaa Capabilities-mittaria sekä UCLA 12 -mittaria arvioimaan yksinäisyyttä. Mittareiden etuna on, että vertailu kaikkiin suomalaisiin on mahdollista.

Alkumittaus osoitti, että pitkäaikaistyöttömien elämänlaatu on merkittävästi heikompi kuin suomalaisten keskimäärin. Pitkäaikaistyöttömien elämänlaatu on noin neljänneksen heikompi kuin suomalaisilla keskimäärin. Alkumittaus myös osoitti, että pitkäaikaistyöttömät kärsivät yksinäisyydestä ja köyhyydestä ja että heidän luottamuksena sekä poliittisiin päättäjiin että julkiseen hallintoon oli vähäistä. Tuloksemme sekä kvalitatiivisesta aineistostamme että kyselystä oli saman suuntainen Helsingin Sanomissa 6.1.2018 julkaistu laajan artikkelin kanssa: köyhät kokevat ulkopuolisuutta, joka saattaa johtaa epätoivoiseen vihaan päättäjiä kohtaan.

Puolen vuoden kuluttua toteutettu seurantamittaus osoitti, että TYPpalveluiden käyttö näyttää parantavan interventioon osallistuneiden hyvinvointia. Merkittävimmät muutokset tapahtuivat fyysisessä elämänlaadussa ja yksinäisyydessä - paradoksaalisesti yksinäisyys näytti lisääntyvän. Kuuden kuukauden seurannan jälkeen $73 \%$ pitkäaikaistyöttömistä oli joko erittäin tai melko tyytyväisiä TYP-palveluihin. He kertoivat, että palveluilla oli ollut heille selvää hyötyä esim. taloudelliseen tilanteeseen, ystävyyssuhteisiin, päivärytmiin ja fyysiseen terveydentilaan. Vain $20 \%$ vastasi, että TYP-palveluilla ei ollut juuri positiivisia vaikutuksia.

Tutkimuksen rajoituksista on syytä sanoa, että seuranta-aika $(6 \mathrm{kk})$ on toki lyhyt, eivätkä muutokset ole kovin suuria. Tilastollista merkitsevyyttä oli vain yhdellä hyvinvoinnin ulottuvuudella: yksinäisyyden lisääntyminen koeryhmässä oli tilastollisesti merkitsevää. Terveydentilan muutos ei mahtunut $95 \%$ luottamusväliin vaikka joissakin versioissa se oli lähellä. Muutokset ovat muilta osin tarkastelluilla mittareilla positiivisia ja kontrolliryhmässä pääsääntöisesti negatiivisia. Näistä rajoituksista huolimatta voidaan todeta, että TYP-palveluihin osallistuminen lisäsi työttömien hyvinvointia.

Terveystaloustieteilijä professori Pekka Rissasen johtama Promeq-hankkeen osatutkimus tutki eri interventioiden kustannus-hyötysuhdetta. TYP-toiminta oli Rissasen tutkimusryhmän mukaan selvästi kustannus-hyötysuhteeltaan kannattavaa. (Rissanen ym. 2019.)

Lopputulema tästä: TYP-toiminta nykyisessä muodossaan on hyödyllistä pitkäaikaistyöttömille. Uskomme, että pitkäaikaistyöttömät ovat erityisryhmä, jota tulee tukea. Heidän hyvinvointinsa heikentäminen (eli nk. keppilinja) ei todennäköisesti johda tulokseen. Siksi pitkäaikaistyöttömien tukemiseen täh- 
tääviä palveluita tulisi kehittää kokeillen erilaisia vaihtoehtoja. Myös kuntien työttömille suunnattuja palveluja olisi hyvä kehittää. Tämä on siis viestini päättäjille: pitkäaikaistyöttömiä pitää kuunnella ja uskoa mitä he sanovat.

\section{MitÄ SOSIAALITYÖN TUTKIJAYHTEISÖ voisi opPIA PromeQ-TUTKIMUKSESTA?}

Ensinnäkin on hämmentävää, miten vähän sosiaalityössä on viime vuosina pohdittu työttömyyttä. Ilmeisesti teemaa pidetään jotenkin niin arkisena, ettei siinä nähdä mitään kiinnostavaa. Olen ollut esittämässä Promeq-hankkeen alusta eli kesästä 2016 lähtien useissa kansainvälisissä ja pohjoismaisissa konferensseissa papereita Promeqin tuloksista. On aivan tavallista, että kohtuullisen kokoisessa kansainvälisessä konferenssissa ei ole ollut muita työttömien palveluihin kohdistuvia tutkimuksia kuin meidän paperimme. Työttömyyttä pitäisi siis tutkia enemmän, mutta ennen kaikkea: pitäisi tutkia keinoja, joilla ihmiset saadaan pois pitkäaikaistyöttömyyden loukusta. Eli pitäisi tutkia aikuissosiaalityön interventioita. Tutkimusta pitäisi tehdä sellaisilla menetelmillä, että päätöksentekijät vakuuttuisivat.

\section{Koeasetelmia kohtaan tunnettu epäluulo}

Valtaosa sosiaalityön tutkimuksesta sekä Suomessa että eri puolilla maailmaa on laadullista tutkimusta. Esimerkiksi suomalaisessa tutkimuksessa aineistot kerätään usein haastatellen suppeaa joukkoa joko sosiaalityöntekijöitä, muita ammattilaisia tai palvelujen käyttäjiä. Ongelmana on, että kerättyä tutkimustietoa on vaikea yleistää koskemaan muita kuin juuri sitä ryhmää ihmisiä, josta tiedot on kerätty. Ei siis ihme, että sosiaalityössä on keskusteltu paljon näyttöön johtavan tiedon luonteesta - usein vielä kannoilla, jotka eroavat vahvasti toisten soveltavien tutkimusalojen näkökulmista.

Yleistäen voi sanoa, että sosiaalityön tutkijoiden parissa vallitsee aika pessimistinen kanta sekä koeasetelmia että standardoituja mittareita kohtaan.Tämä on niin yleistä suomalaisessa sosiaalityön tutkimuksessa, että vaikuttavuuden tutkimuksesta kiinnostuneetkaan tutkijat eivät edes harkitse minkäänlaisten vertailuasetelmien kokeilemista. Tätä tilannetta ei ole myöskään muuttamassa se ylenpalttinen usko kvalitatiivisten, lähinnä haastatteluihin perustuvien, aineistojen kykyyn tuottaa "syvällistä" ja monipuolista tietoa, vaikkei ehkä sosiaalityön vaikuttavuudesta, niin ainakin asiakkaiden elämästä ja kokemuksista. Siksi ei ole lainkaan ihme, että tutkimuskirjallisuudessa on hyvin vähän esimerkkejä onnistuneista koeasetelmien soveltamisista.

Käsityksemme mukaan suomalaisessa sosiaalityön tutkimuksessa ei ole juurikaan sovellettu koeasetelmia, ei varsinkaan satunnaistettuja koeasetelmia, mutta myös kaikenlaisista kvasikokeellisista ja vertailuasetelmista on vain vähän, jos lainkaan kokemuksia. ${ }^{3}$

Vaikka puhtaaseen satunnaistettuun koeasetelmaan ei yhteiskuntatieteellisessä eikä sosiaalityön tutkimuksessa taida kovin usein olla mahdollisuutta, ei tämä silti tarkoita, etteikö toimenpiteiden vaikuttavuutta voitaisi arvioida koe- ja kontrolliryhmiä käyttämällä, jos tutkimuksessa hyödynnetään kaltaistamista. Kaltaistamiseen perustuvassa tutkimusasetelmassa eettiset ongelmat 
ovat samankaltaisia kuin muissakin sosiaalityön tutkimuksissa. Promeq-tutkimuksesta saadut kokemukset osoittavatkin koeasetelmaa koskevat epäilyt liioitteleviksi. PSM:n käyttöä sosiaalityön vaikuttavuustutkimuksessa tulisikin edistää. Koe- ja kontrolliryhmien vertaaminen kaltaistamalla tulisi nostaa sosiaalityön koulutuksessa tutkimusmenetelmällisen osaamiseen keskiöön.

\section{Talousnäkökulma}

Promeq on ollut monitieteinen tutkimushanke. Siksi meillä on ollut mahdollisuus tehdä yhteistyötä taloustieteilijöiden kanssa. Sosiaalialan palveluista ei ole juuri ilmestynyt kustannushyötyanalyyseja. Jatkossa sellaisen tutkimuksen, joka ottaa vakavasti myös palvelujen kustannukset, merkitys kasvaa.

Yhteenvetona voimme todeta, että sosiaalityön akateemisessa keskustelussa liitetyt epäilyt koeasetelmien soveltamismahdollisuuksista ovat ylimitoitettuja. Sosiaalityön tutkimukseen liittyy aina eettisiä haasteita, kuten tutkijoiden vastuu tutkimukseen osallistuvien hyvinvoinnista - ja tämän vastuun rajat. Nämä huolet koskevat myös koeasetelmapohjaisia tutkimuksia, samoin kuin mahdolliset ja käytettävissä olevat ratkaisukeinot. Viestini sosiaalityön tutkijayhteisölle on: ei kannata pelätä koeasetelmia, sillä joskus ne ovat ainoa mielekäs tapa tutkia vaikuttavuutta.

\section{Promeqin kokemuksia}

Promeq WP4 on voitu toteuttaa ilman, että olisimme joutuneet tinkimään tutkimuksen etiikasta. Ongelmia voisi nousta esiin esimerkiksi lastensuojeluun liittyvässä tutkimuksessa, mutta sielläkin uusia työmenetelmiä on mahdollista kokeilla ja testata käyttämällä vertailuryhmänä vallitsevaa toimintatapaa. Käsityksemme mukaan sosiaalityö ei tässä suhteessa eroa vaikkapa psykologin tai psykiatrin työstä.

Erittäin tärkeältä tuntuu Promeq-konsortiossa syntyvä mahdollisuus yhdistää erilaisia lähestymistapoja yhteisten aineistojen analysoinnissa. Siksi tutkimuksessamme kerättyä aineistoa on voitu hyödyntää myös hyvinvoinnin taloustieteen näkökulmasta tehtyyn kustannus-vaikuttavuusanalyysiin. Interventioiden vaikuttavuudesta puhuminen ilman kustannusnäkökulmaa ei ole hyväksi. (Scriven 1992.)

Tutkimusasetelmamme rakentamisessa käytetystä menetelmästä eli PSM:n avulla totetetusta pareittaisesta vertailusta saadut kokemukset ovat hyviä. Mielestämme PSM:n käyttöä pitäisi sosiaalityön vaikuttavuustutkimuksessa jatkaa. Vaikka satunnaistetuilla koeasetelmilla varmaan saadaankin monessa suhteessa luotettavaa tietoa tutkitun menetelmän vaikutuksista, tarjoaa PSM kätevän tavan toteuttaa varsin luotettavia tuloksia menetelmien vaikuttavuuden arviointiin ilman tiukan satunnaistetun koeasetelman rakentamiseen liittyviä haasteita.

\section{JоHторÄÄTÖKSIÄ}

Lopuksi muutama sana Jyväskylän yliopiston sosiaalityön tutkimuksesta ja opetuksesta. Kun aloitin Jyväskylässä 2001, oli yksikkömme pieni sekä henkilökunta- että opiskelijamäärältään. Vähitellen opiskelijoiden ja valmistuneiden määrä kasvoi, ensin maisteri- ja sitten myös tohtoritutkinnoissa. Yhteistyö Kokkolan 
yliopistokeskus Chydeniuksen sosiaalityön yksikön kanssa on tehnyt Jyväskylän yliopiston sosiaalityön koulutuksesta valtakunnallisesti vahvan toimijan.

Jyväskylän yliopiston sosiaalityössä on haettu synergiaa varsin erilaisten kiinnostuksenkohteiden välillä: meillä on keskusteltu filosofien kanssa sosiaalialan normatiivisesta perustasta, tehty yhteistyötä kauppakorkeakoulun laskentatoimen kanssa, tutkittu lähisuhdeväkivaltaa psykologien ja toisten yhteiskuntatieteilijöiden kanssa, tehty evaluaatiotutkimuksia ... ja nyt puhuin vain omista kiinnostuksen kohteistani. Uskon, että meillä on ollut oma, vahva profiilimme, vaikka se onkin fokusoitunut aika poikkeuksellisella tavalla ja on vaikeasti puristettavissa Twitterin mittaisiksi iskulauseiksi.

Vuodet Jyväskylässä ovat olleet työntäyteisiä. Kiitän hyviä työtovereitani, ystäviä ja kollegoita, opiskelijoita! On ollut ilo saada työskennellä kanssanne.

\section{VIITTEET}

1 Puheenvuoro perustuu Jyväskylän yliopistossa 9.1.2019 pidettyyn jäähyväisluentoon.

2 HS:n 8.1.2019 mukaan näyttää aika epätodennäköiseltä, että maakuntauudistusta koskevat lait ehdittäisiin käsittelemään tämän eduskunnan aikana.

3 Yliopistokirjastojen Melinda-tietokannan 27.11.2018 asiasanoihin "sosiaalityö" AND "koeasetelma" suunnattu haku tuotti tyhjän tuloksen.

\section{KiRJALlisuUs}

Hänninen, Sakari \& Karjalainen, Vappu (2012) Työttömien ja vaikeassa asemassa olevien terveyteen ja toimintakykyyn vai- kuttaminen. Teoksessa Sakari Hänninen \& Maijaliisa Junnila (toim.) Vaikuttavatko politiikkatoimet? Helsinki:THL, 77-84.

Parsons, Lori S. (2001) Reducing Bias in a Propensity Score Matched-Pair Sample Using Greedy Matching Techniques. Proceedings of the Twenty-Sixth Annual SAS Users. Paper 214-26 in Proceedings of the Twenty-Sixth Annual SAS Users Group International Conference, 214-226.

Rissanen, Pekka \& Klavus, Jan \& Forma, Leena (2019) Haavoittuvassa asemassa olevien väestöryhmien hyvinvoinnin kohentamiseen on kustannusvaikuttavia keinoja. PROMEQ Policy Brief. Politiikkasuositus 7.

Rosenbaum, Paul R. \& Rubin, Donald B. (2006) The central role of the propensity score in observational studies for causal effects. Teoksessa Donald D. Rubin (toim.) Matched Sampling for Causal Effects. Cambridge: Cambridge University Press, 170-184. https://doi.org/10.1017/ CBO9780511810725.016

Sage, Daniel (2013) Activation, health and well-being: neglected dimensions? International Journal of Sociology and Social Policy, 33 (1-2), 4-20. https://doi. org/10.1108/01443331311295145

Sage, Daniel (2015) Do Active Labour Market Policies Promote the Well-Being, Health and Social Capital of the Unemployed? Evidence from the UK. Social Indicators Research, 124 (2), 319-337. https://doi.org/10.1007/s11205-0140788-2

Scriven, Michael (1992) Evaluation Thesaurus (4. p.). Newbury Park,CA: Sage.

Shaw, Ian (2016) Social Work Science. New York: Columbia University Press.

Valtioneuvosto. (2018) Hallituksen esitys eduskunnalle laieiksi julkisista rekrytointipalveluista ja osaamisen kehittämispalveluista, alueiden kehittämisen ja kasvupalvelujen rahoittamisesta, yksityisistä työnvälityspalveluista sekä taloudelliseen toimintaan myönnettävän tuen yleisistä edellytyksistä annetun lain 1 ja 2 \:n muuttamisesta. Helsinki:Valtioneuvosto.

Webb, Stephen A. (2018) Ian Shaw - Social Work Science. Review. Critical Social Policy, 38 (1), 172-174. https://doi. org/10.1177/0261018317733081c 